\title{
IN SILICO EVALUATION OF SELECTED BENZIMIDAZOLE DERIVATIVES IN THE DISCOVERY OF NEW POTENT ANTIMICROBIAL AGENTS
}

\author{
Jelena V. Živković, Sandra G. Kalauzović, Maja R. Milosavljević, Kristina G. Kalauzović \\ Benzimidazoles are heterocyclic compounds that represent pharmacophores of many \\ drugs. Apart from antimicrobial (antibacterial and antifungal) activities, benzimidazole derivati- \\ ves are remarkably effective compounds possessing a wide spectrum of biological activities. \\ Pharmacokinetic and toxicological properties of forty-two benzimidazole derivatives were cal- \\ culated using Molinspiration, SwissADME and OSIRIS Data Warrior. The properties of benzimi- \\ dazoles were compared to those of doxycycline, chloramphenicol and ketoconazole. The com- \\ pounds met all criteria for satisfying oral bioavailability. The majority of tested benzimidazoles is \\ considered non-toxic, and the irritating behaviour was not observed in any of the cases. Finally, \\ the most promising nine derivatives were selected on the basis of favourable pharmacokinetic \\ parameters and toxicological characteristics. The ability to pass through the hematoencephalic \\ barrier is expected for all components except one, and none of the selected components is a \\ substrate for P-glycoprotein. In addition, metabolic properties are favourable since all the \\ selected components are expected to inhibit not more than three Cytochrome P450 isoenzymes \\ and to be non-toxic.
}

Acta Medica Medianae 2019;58(1):106-115.

Key words: antimicrobial agents, benzimidazoles, bioavailability, in silico study, toxicological characteristics University of Niš, Faculty of Medicine, Department of Pharmacy,
Niš, Serbia

Contact: Jelena V. Živković

Blvd dr Zoran Djindjić 81, 18000 Niš, Serbia

E-mail: jelena.zivkovic.hemija@medfak.ni.ac.rs

\section{Introduction}

Antimicrobial drugs are nowadays widely used. Antimicrobial resistance compromises successful prevention and treatment of an increasing number of infections (1). To overcome these challenges, novel agents should have different chemical characteristics in relation to existing agents. Therefore, the synthesis of new compounds which have structural similarities with already known biologically active molecules is done.

Benzimidazoles are organic, heterocyclic compounds that represent pharmacophores of many drugs (2). Due to their therapeutic significance, these compounds attract the attention of many researchers. 5,6-Dimethylbenzimidazole is an integral part of the chemical structure of vitamin B12, and it has been found that other derivatives of benzimidazole have the activity similar to that of vitamin B12 (3). 106
Benzimidazole and its derivatives can serve as model components for purine because of the similarities in chemical structure (4). It is considered that antibacterial ability of these compounds is, among everything else, precisely the result of competition with purine bases which results in the inhibition of nucleic acid and cell wall protein synthesis $(4,5)$. Fungicidal mechanisms of this component are facilitated by inhibition the synthesis of estrogen, which is a component of the cell membrane of fungi $(6,7)$. Apart from antimicrobial properties, various substituted derivatives of benzimidazole nucleus induce anthelmintic (2), antihypertensive (8), anti-inflammatory (9), antiviral (10), antioxidative (11), anticancerogenic (12), anticoagulative effects (13), as well as many other downstream activities.

Methods of a computer - based (in silico) analysis can considerably accelerate the rate of discovery of new drug candidates because such methods are extremely fast, thereby reducing the need for expensive lab work and clinical trials. In the present study, in silico drug likeliness assessment, as well as evaluation of bioavailability and toxicological characteristics of benzimidazole derivatives, were pursued in the quest to discover new potent antimicrobial agents.

\section{Aim}

The aim of this research is to present in silico evaluation of physicochemical properties, pharma- 
cokinetic parameters and toxicity potential of benzimidazole derivatives.

\section{Material and methods}

Data sources for in silico assessment

The structures of benzimidazole derivatives ( $n$ $=42$ ) included in the study were selected from the literature. Compounds bearing 2-aminobenzimidazole (1-3) and hydrazone moieties (4-17) were presented in the study by Özkay et al. 2011 (14). They reported that synthesized novel benzimidazole-hydrazone exhibited low antibacterial activity, while in contrast the compound showed significant antifungal activity against Candida yeasts. 1,3-Disubstitutedbenzimidazol-2-imines (18-22) and 2-substituted1,3-thiazolo [3,2-a] benzimidazolones (23-28) were studied with respect to their antibacterial activity against Gram-positive and Gram-negative bacteria
(15). 1,3-Diphenylpropyl-5-methyl-1,3-dihydro-2Hbenzimidazol-2-imine (22) possessed significant activity against $B$. subtilis, S. aureus, S. abony and $E$. coli. The group of thiazolobenzimidazolones did not express their antibacterial activity against tested strains. 2-Methylbenzimidazole (29), 1-substituted2-methylbenzimidazoles (30-35), 2-aminobenzimidazole (36) and 1-substituted-2-aminobenzimidazoles (37-42) were previously reported to express effective antifungal activity against Saccharomyces cerevisiae (6).

The properties of benzimidazoles were compared to antibacterial drugs doxycycline and chloramphenicol, as well as an antifungal agent - ketoconazole. The chemical structure of the compounds was drawn using ChemDraw (16) (Figure 1), and their Simplified Molecular Input Line Entry System (SMILES) notations were generated.
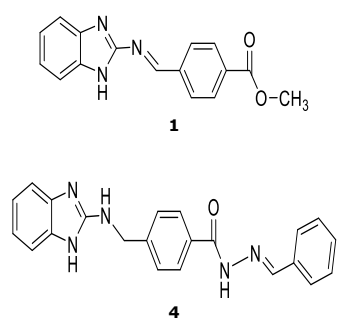<smiles>O=C(N/N=C/c1ccc(O)cc1)c1ccc(CNc2nc3ccccc3[nH]2)cc1</smiles><smiles>COc1ccc(/C=N/NC(=O)c2ccc(CNc3nc4ccccc4[nH]3)cc2)cc1</smiles>

10<smiles></smiles>

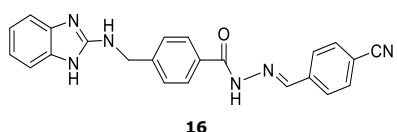<smiles>O=C(O)c1ccc(/C=N/NC(=O)c2ccc(CNc3nc4ccccc4[nH]3)cc2)cc1</smiles>

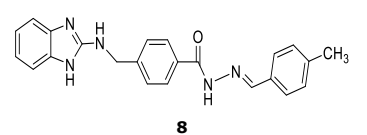<smiles>O=C(N/N=C/c1ccc(Cl)cc1)c1ccc(CNc2nc3ccccc3[nH]2)cc1</smiles><smiles>O=C(N/N=C/c1ccc([N+](=O)[O-])cc1)c1ccc(CNc2nc3ccccc3[nH]2)cc1</smiles>
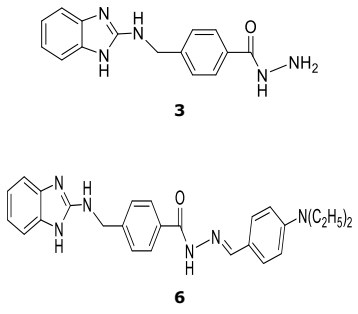<smiles>COc1ccc(/C=N/NC(=O)c2ccc(CNc3nc4ccccc4[nH]3)cc2)cc1</smiles><smiles>O=C(N/N=C/c1ccc(Br)cc1)c1ccc(CNc2nc3ccccc3[nH]2)cc1</smiles><smiles>O=C(N/N=C/c1ccc(C(F)(F)F)cc1)c1ccc(CNc2nc3ccccc3[nH]2)cc1</smiles><smiles>Cc1ccc2c(c1)n(CC(=O)c1ccccc1)c(=N)n2CC(=O)c1ccccc1</smiles><smiles>N=c1n(CC(=O)c2ccccc2)c2ccc([N+](=O)[O-])cc2n1CC(=O)c1ccccc1</smiles>

19

20 


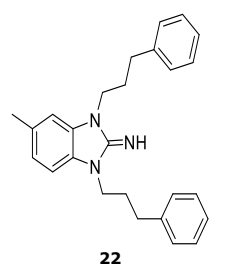

22
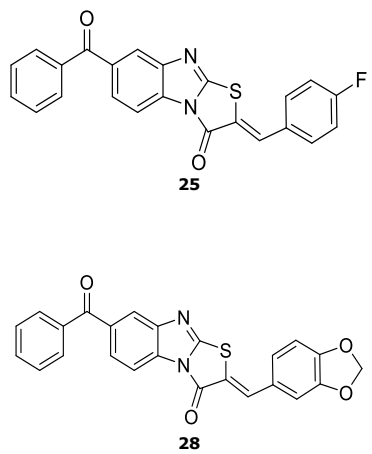<smiles>Cc1ccc(Cn2c(C)nc3ccccc32)cc1</smiles>

31

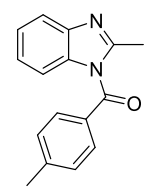

34

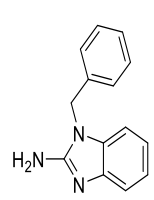

37

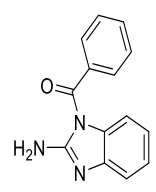

40

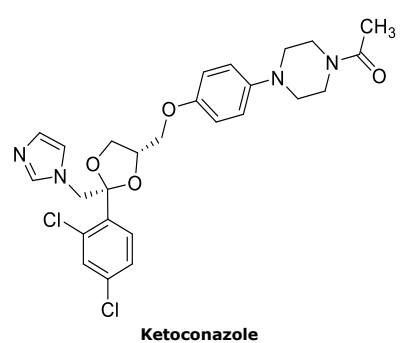<smiles>O=C(O)CSc1cccc(C(=O)c2ccccc2)n1</smiles><smiles>O=C(c1ccccc1)c1ccc2c(c1)nc1s/c(=C\c3ccccc3F)c(=O)n12</smiles>
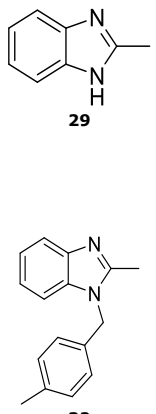

32
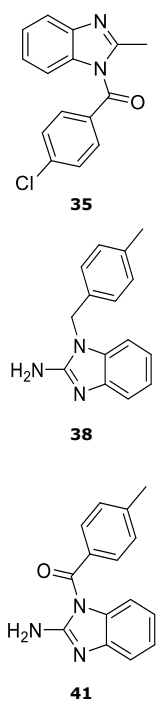

$\mathrm{H}_{3} \mathrm{C}, \mathrm{CH}_{3}$

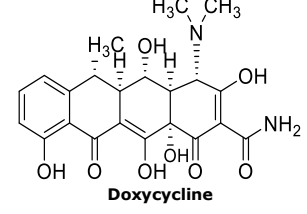

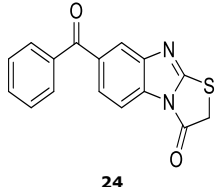

24
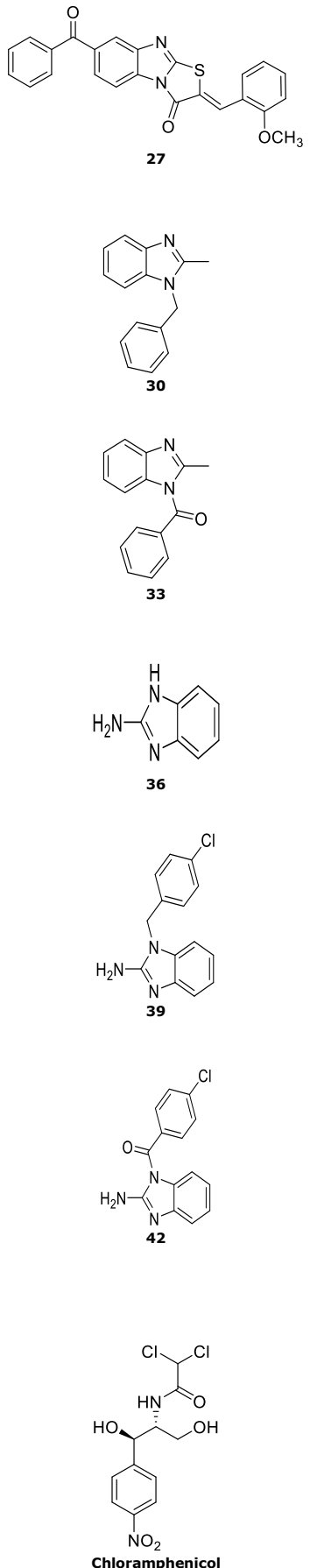

Figure 1. Chemical structure of benzoimidazoles derivatives and standards 
In silico evaluation of drug-likeness, pharmacokinetic parameters and toxicological characteristics

SMILES notations of the selected compounds were fed in the Molinspiration software version 2011. 06 (17) for calculating drug-likeness properties (logarithm of the partition coefficient between n-octanol and water, total polar surface area, number of hydrogen bond donors and acceptors, molecular weight, etc.) and the prediction of bioactivity score for drug targets (G protein-coupled receptor (GPCR) and nuclear receptor ligands, ion channel modulators, as well as protease, kinase and enzyme inhibitors). A molecule having bioactivity score more than 0.00 is most likely to exhibit considerable biological activities, while values -0.50 to 0.00 are expected to be moderately active. If the score is less than -0.50 , the molecule is presumed to be inactive (13).

Table 1. Drug likeness score for compounds predicted by Molinspiration (17)

\begin{tabular}{|c|c|c|c|c|c|c|c|c|c|}
\hline Compound & miLogPa & $\begin{array}{c}\text { TPSA }^{\mathrm{b}} \\
\left(\AA^{2}\right) \\
\end{array}$ & natoms ${ }^{c}$ & $\begin{array}{c}\mathrm{Mw}^{\mathrm{d}} \\
(\mathrm{g} / \mathrm{mol}) \\
\end{array}$ & $\mathrm{nON}^{\mathrm{e}}$ & $\mathrm{nOHNH}^{f}$ & nviolations $^{g}$ & nrotb $^{h}$ & $\begin{array}{c}\text { volume } \\
\left(\AA^{3}\right) \\
\end{array}$ \\
\hline 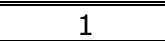 & 1.78 & 56.40 & 11 & 147.13 & 3 & 0 & 0 & 2 & 127.80 \\
\hline 2 & 3.18 & 67.02 & 21 & 281.31 & 5 & 2 & 0 & 5 & 254.01 \\
\hline 3 & 1.39 & 95.83 & 21 & 281.32 & 6 & 5 & 0 & 4 & 252.15 \\
\hline 4 & 4.17 & 82.17 & 28 & 369.43 & 6 & 3 & 0 & 6 & 335.53 \\
\hline 5 & 4.27 & 85.41 & 31 & 412.50 & 7 & 3 & 0 & 7 & 381.44 \\
\hline 6 & 5.02 & 85.41 & 33 & 440.55 & 7 & 3 & 1 & 9 & 415.04 \\
\hline 7 & 3.69 & 102.40 & 29 & 385.43 & 7 & 4 & 0 & 6 & 343.55 \\
\hline 8 & 4.62 & 82.17 & 29 & 383.45 & 6 & 3 & 0 & 6 & 352.09 \\
\hline 9 & 4.22 & 91.41 & 30 & 399.45 & 7 & 3 & 0 & 7 & 361.08 \\
\hline 10 & 4.60 & 91.41 & 31 & 413.48 & 7 & 3 & 0 & 8 & 377.88 \\
\hline 11 & 4.84 & 82.17 & 29 & 403.87 & 6 & 3 & 0 & 6 & 349.07 \\
\hline 12 & 4.98 & 82.17 & 29 & 448.32 & 6 & 3 & 0 & 6 & 353.42 \\
\hline 13 & 4.33 & 82.17 & 29 & 387.42 & 6 & 3 & 0 & 6 & 340.46 \\
\hline 14 & 4.13 & 128.00 & 31 & 414.43 & 9 & 3 & 0 & 7 & 358.87 \\
\hline 15 & 5.06 & 82.17 & 32 & 437.43 & 6 & 3 & 1 & 7 & 366.83 \\
\hline 16 & 3.92 & 105.96 & 30 & 394.44 & 7 & 3 & 0 & 6 & 352.39 \\
\hline 17 & 4.08 & 119.47 & 31 & 413.44 & 8 & 4 & 0 & 7 & 362.53 \\
\hline 18 & 2.83 & 67.86 & 29 & 383.45 & 5 & 1 & 0 & 6 & 352.02 \\
\hline 19 & 2.34 & 113.69 & 31 & 414.42 & 8 & 1 & 0 & 7 & 358.79 \\
\hline 20 & 2.02 & 103.40 & 30 & 409.44 & 8 & 1 & 0 & 10 & 367.73 \\
\hline 21 & 1.01 & 86.33 & 23 & 319.36 & 7 & 1 & 0 & 8 & 293.89 \\
\hline 22 & 5.18 & 33.72 & 29 & 383.54 & 3 & 1 & 1 & 8 & 381.26 \\
\hline 23 & 3.02 & 83.05 & 22 & 312.35 & 5 & 2 & 0 & 5 & 261.19 \\
\hline 24 & 3.59 & 51.97 & 21 & 294.33 & 4 & 0 & 0 & 2 & 242.71 \\
\hline 25 & 5.30 & 51.45 & 29 & 400.43 & 4 & 0 & 1 & 3 & 329.67 \\
\hline 26 & 5.25 & 51.45 & 29 & 400.43 & 4 & 0 & 1 & 3 & 329.67 \\
\hline 27 & 5.15 & 60.68 & 30 & 412.47 & 5 & 0 & 1 & 4 & 350.28 \\
\hline 28 & 5.03 & 69.92 & 31 & 426.45 & 6 & 0 & 1 & 3 & 348.66 \\
\hline 29 & 1.52 & 28.68 & 10 & 132.117 & 2 & 1 & 0 & 0 & 125.42 \\
\hline 30 & 3.18 & 17.83 & 17 & 222.29 & 2 & 0 & 0 & 2 & 214.02 \\
\hline 31 & 3.63 & 17.83 & 18 & 236.32 & 2 & 0 & 0 & 2 & 230.58 \\
\hline 32 & 3.86 & 17.83 & 18 & 256.74 & 2 & 0 & 0 & 2 & 227.55 \\
\hline 33 & 3.06 & 34.90 & 18 & 236.27 & 3 & 0 & 0 & 1 & 216.20 \\
\hline 34 & 3.51 & 34.90 & 19 & 250.30 & 3 & 0 & 0 & 1 & 232.76 \\
\hline 35 & 3.73 & 34.90 & 19 & 270.72 & 3 & 0 & 0 & 1 & 229.74 \\
\hline 36 & 1.23 & 54.71 & 10 & 133.15 & 3 & 3 & 0 & 0 & 120.15 \\
\hline 37 & 2.90 & 43.85 & 17 & 223.28 & 3 & 2 & 0 & 2 & 208.75 \\
\hline 38 & 3.34 & 43.85 & 18 & 237.31 & 3 & 2 & 0 & 2 & 225.31 \\
\hline 39 & 3.57 & 43.85 & 18 & 257.72 & 3 & 2 & 0 & 2 & 222.28 \\
\hline 40 & 2.77 & 60.92 & 18 & 237.26 & 4 & 2 & 0 & 1 & 210.93 \\
\hline 41 & 3.22 & 60.92 & 19 & 251.29 & 4 & 2 & 0 & 1 & 227.49 \\
\hline 42 & 3.45 & 60.92 & 19 & 271.71 & 4 & 2 & 0 & 1 & 224.46 \\
\hline KTC & 3.77 & 69.08 & 36 & 531.44 & 8 & 0 & 1 & 7 & 452.47 \\
\hline DOX & -0.43 & 181.61 & 32 & 446.44 & 10 & 7 & 1 & 2 & 377.79 \\
\hline $\mathrm{CHL}$ & 0.73 & 115.38 & 20 & 323.13 & 7 & 3 & 0 & 6 & 249.16 \\
\hline
\end{tabular}

a Logarithm of the partition coefficient between n-octanol and water (miLogP); b Topological polar surface area (TPSA);

c Number of nonhydrogen atoms; d Molecular weight; e Number of hydrogen bond acceptors ( $\mathrm{O}$ and $\mathrm{N}$ atoms);

$\mathrm{f}$ Number of hydrogen bond donors (OH and NH groups); g Number of Rule of 5 violations;

h Number of rotatable bonds (n-rotb); i Molecular volume; j KTC - ketoconazole; k DOX - doxycycline

I CHL - chloramphenicol. 
The list of SMILES was then entered in SwissADME (18) for generating the prediction of gastrointestinal absorption, brain penetration and substrates for P-glycoprotein. In addition, the analysis of ADMET absorption properties was done to check whether those compounds were inhibitors of five isoforms of Cytochrome P450 (CYP) family. Further, OSIRIS Data Warrior was used for the prediction of the comounds' mutagenic and tumorigenic risks, reproductive and irritant effects (19).

\section{Results and discussion}

Calculated physicochemical properties of the studied molecules using Molinspiration (17) are presented in Table 1.

Based on the obtained results, all examined compounds are likely to have good biological availability given the fact that they do not violate more than one of Lipinski's rules (Table 1) $(20,21)$. Lipinski's 'Rule of Five' (RO5) is a rule of thumb used to evaluate drug-likeness. RO5 is commonly used by medicinal chemists in drug design as a simple set of physicochemical parameter ranges associated with $90 \%$ of orally active drugs that achieved Phase II status (22). Lipinski specifically states that RO5 only holds for compounds that are absorbed by passive mechanisms (23). All examined benzimidazole derivatives are lipophilic drugs $(\log P>1$ ) (Table 1$)$.
Compounds 6, 15, 22, 25-28 have (log $P>5$ ) and consequently show one violation of RO5. Ketoconazole and chloramphenicol are lipophilic, whereas doxycyline ( $\log P=-0.43$ ) is a hydrophilic compound which affects its bioavailability and way of administration.

Topological polar surface area (TPSA) is very much correlated with hydrogen bonding of a molecule and is a very good indicator of the bioavailability of a drug molecule. Veber et al. 2002. (21) defined a rule for drug-likeness on strains as nrotb $\leq 10$ and TPSA $\leq 140 \AA^{2}$. In addition, a drug can be absorbed over $90 \%$ if the TPSA value is $<60 \AA^{2}(24)$.

The number of rotatable bonds (nrotb) higher than 10 was not determined in neither of the components, which is considered another sign of expected good oral bioavailability (Table 1). TPSA of benzimidazole derivatives was observed in the range of 17.83-128.00 $\AA^{2}$ and is well below the limit of 140 $\AA^{2}$. The TPSA value for antifungal drug doxycycline is $181.61 \AA^{2}$, while the other two antibacterial agents have values below $140 \AA^{2}$.

The molecular weight of forty-two benzimidazole derivatives was found to be less than 500 $\mathrm{g} / \mathrm{mol}$ and thus these molecules are expected to be easily transported, diffused and absorbed in comparison to large molecules. Among standard antimicrobial drugs, only ketoconazole had a higher $\mathrm{Mw}$ $(531.44 \mathrm{~g} / \mathrm{mol})$.

Table 2. Bioactivity score of compounds according to Molinspiration (17)

\begin{tabular}{|c|c|c|}
\hline Drug targets & Activity & Compound \\
\hline GPCR ligand & $\begin{array}{l}\mathrm{CST}^{\mathrm{a}} \\
\text { active }\end{array}$ & $6(22,35,39-42)$ and KTC \\
\hline GPCR ligand & $\begin{array}{l}\text { Mod. }^{\mathrm{b}} \\
\text { active }\end{array}$ & $30(1-21,23,24,30-34,37,38)$ and $\mathrm{DOX}, \mathrm{CHL}$ \\
\hline GPCR ligand & Inactive & $6(25-29,36)$ \\
\hline $\mathrm{ICM}^{\mathrm{C}}$ & $\begin{array}{l}\text { CST } \\
\text { active }\end{array}$ & $5(6,9,36,37,39)$ \\
\hline ICM & $\begin{array}{l}\text { Mod. } \\
\text { active }\end{array}$ & $\begin{array}{l}28(1-5,7,8,10,11,13-17,20,22,23,29-35,38,40-42) \text { and KTC, } \\
\text { DOX }, \mathrm{CHL}\end{array}$ \\
\hline ICM & Inactive & $9(12,18,19,21,24-28)$ \\
\hline Kinase inhibitor & $\begin{array}{l}\text { CST } \\
\text { active }\end{array}$ & $7(2,3,5,7,13,15,16)$ \\
\hline Kinase inhibitor & $\begin{array}{l}\text { Mod. } \\
\text { active }\end{array}$ & $30(1,4,6,8-12,14,17-28,30-38)$ and $\mathrm{KTC}, \mathrm{CHL}$ \\
\hline Kinase inhibitor & Inactive & $5(29,39-42)$ and DOX \\
\hline$N R L^{d}$ & $\begin{array}{l}\text { CST } \\
\text { active }\end{array}$ & $1(1)$ \\
\hline NRL & $\begin{array}{l}\text { Mod. } \\
\text { active }\end{array}$ & $16(2,15,17,20,22-24,30-35,40-42)$ and KTC, DOX, CHL \\
\hline NRL & Inactive & $25(3-14,16,18,19,21,25-29,36-39)$ \\
\hline $\begin{array}{l}\text { Protease } \\
\text { inhibitor }\end{array}$ & $\begin{array}{l}\text { CST } \\
\text { active }\end{array}$ & / \\
\hline $\begin{array}{l}\text { Protease } \\
\text { inhibitor }\end{array}$ & $\begin{array}{l}\text { Mod. } \\
\text { active }\end{array}$ & $\begin{array}{l}30(2-7,9-11,13,15-17,18-20,22,23,30-35,37-42) \text { and KTC, } \\
\text { DOX, CHL }\end{array}$ \\
\hline $\begin{array}{l}\text { Protease } \\
\text { inhibitor }\end{array}$ & Inactive & $12(1,8,12,14,21,24-29,36)$ \\
\hline $\begin{array}{l}\text { Enzyme } \\
\text { inhibitor }\end{array}$ & $\begin{array}{l}\text { CST } \\
\text { active }\end{array}$ & $12(3,4,23,33-35,37-42)$ and KTC \\
\hline $\begin{array}{l}\text { Enzyme } \\
\text { inhibitor }\end{array}$ & $\begin{array}{l}\text { Mod. } \\
\text { active }\end{array}$ & $29(1,2,5-22,24-28,30-32,36)$ and $\mathrm{CHL}$ \\
\hline $\begin{array}{l}\text { Enzyme } \\
\text { inhibitor }\end{array}$ & Inactive & 1 (29) and DOX \\
\hline
\end{tabular}

a CST - Considerable; b Mod. - moderate; c ICM - Ion channel modulator; d NRL- Nuclear receptor ligand 
Table 3. Absorption properties of compounds predicted by SwissADME (18)

\begin{tabular}{||l||l||}
\hline \hline Absorption properties & Compound \\
\hline High HIA & $40(1-7,9-13,15-42)$ and KTC, CHL \\
\hline Low HIA & $2(8,14)$ and DOX \\
\hline BBB $^{\mathrm{b}}$ permeant & $19(1,2,18,22,24,29-42)$ and KTC \\
\hline Non-BBB permeant & $23(3-17,19-21,23,25-28)$ and DOX, CHL \\
\hline Substrates for P-gp & $6(3,8,22,37-39)$ and DOX \\
\hline Non-Substrates for P-gp & $36(1,2,4-7,9-21,23-36,40-42)$ and KTC, CHL \\
\hline
\end{tabular}

Table 4. Metabolic properties of compounds according to SwissADME (18)

\begin{tabular}{||l||l||}
\hline Metabolic properties & Compound \\
\hline CYP1A2 inhibitor & $34(1-5,7,9-13,15-17,22-27,29-42)$ \\
\hline CYP2C19 inhibitor & $36(1,2,4-7,9-20,22,24-28,30-35,37-42)$ and KTC \\
\hline CYP2C9 inhibitor & $27(1,4-7,9-20,22-28,34,35,42)$ and KTC \\
\hline CYP2D6 inhibitor & $18(2,4-7,9-13,16,22,30-32,37-39)$ and KTC \\
\hline CYP3A4 inhibitor & $19(4-6,9-16,18,22,27,30,31,37-39)$ and KTC \\
\hline \hline
\end{tabular}

The hydrogen bonding capacity of benzimidazoles, described by the number of hydrogen bond donors and acceptors, differs significantly. They show 2 to 9 hydrogen bond acceptors and 0 to 5 hydrogen bond donors. In the group of standard drugs, ketoconazole shows 10 hydrogen bond acceptors and 7 hydrogen bond donors and consequently manifests one RO5 violation.

The volume of molecules determines the transport of molecules through the intestinal and hematoencephalic barrier. By increasing the volume of molecules, which can be considered a valid parameter of the assessment of oral bioavailability, the number of rotatable bonds also increases, as well as the number of hydrogen bonds (17).

None of the molecules show volume of more than $500 \AA^{3}$. The presented results of physicochemical properties indicate that good intestinal absorption is predicted for all investigated compounds.

The bioactivity scores of listed compounds for drug targets were also predicted by Molinspiration (17) (Table 2).

The obtained results (Table 2 ) clearly demonstrate that the physiological actions of benzimidazole derivatives might involve multiple mechanisms and, which could be the result of interactions with GPCR ligands, nuclear receptor ligands, inhibit protease, kinase and other enzymes. The bioactivity score of compounds is suggestive of most components of mainly moderate interactions with all drug targets. However, the compounds are assumed to exhibit the weakest biological activities with nuclear receptor ligands, because twenty-five benzimidazoles are predicted to be inactive. The most promising twentynine compounds which are predicted to act by more than four mechanisms are identified as 1-7, 9-13, $15-17,20,22,23,30-35,37-39,41,42$. Ketoconazole and chloramphenicol may have effects on all proposed drug targets, while doxycycline is a little less active due to the lack of kinase and enzyme inhibitors' activity.
Absorption and metabolic properties of the compounds were predicted by SwissADME (18) (Table 3 and Table 4).

SwissADME enables predictions for passive human gastrointestinal absorption (HIA) and blood-brain barrier (BBB) permeation of compounds, as well as the assessment of whether a compound is a substrate of P-gp and an inhibitor of CYP isoenzyme family (18, 23). The knowledge about compounds being substrates or non-substrates of P-gp is essential for the evaluation of active efflux through biological membranes. A crucial role of $\mathrm{P}$-gp is to prevent intracellular accumulation of toxic compounds and to protect the central nervous system (CNS) from xenobiotics (25, 26).

The analysis of benzimidazole derivatives using SwissADME shows that all compounds, except for 8 and 14, are expected to have good gastrointestinal (GIT) absorption. The ability to pass through the hematoen-cephalic barrier is predicted for nineteen compounds. Furthermore, it was determined that only six compounds can be substrates for P-glycoprotein. Ketoconazole and chloramphenicol are predicted to have high HIA, permeant BBB is expected for ketoconazole, and doxycycline is expected to be a substrate for P-gp (Table 3).

The superfamily of CYP isoenzymes is crucial for drug elimination through phase I of metabolic biotransformation. CYP and P-gp are likely to metabolize small molecules synergistically to improve protection of tissues and organisms. Therapeutic molecules are substrates of five major isoforms of CYP enzyme family: CYP1A2, CYP2C19, CYP2C9, CYP2D6 and CYP3A4. The inhibition of these isoenzymes is certainly a major cause of pharmacokinetics-related drug-drug interactions, which could induce toxic or other undesirable adverse effects (26).

Seven compounds, 4, 9-13 and 22, are predicted to inhibit all the listed CYP isoenzymes. The least numbers of compounds, eighteen, will probably inhibit isoenzymes CYP2D6. Ketoconazole is predict- 
ed to inhibit 4 enzyme subfamilies, whereas doxycycline and chloramphenicol are not predicted to have an inhibitory effect on CYP enzymes (Table 4).
Toxicological properties of the compounds predicted by OSIRIS Data Warrior (19) are shown in Table 5.

Table 5. Predicted toxicological properties of compounds by OSIRIS Data Warrior (19)

\begin{tabular}{||l|l|l||}
\hline \multirow{2}{*}{ Toxicological properties } & Level & \multicolumn{1}{c|}{ Compound } \\
\hline Mutagenic risk & High & $14(6,14,18-22,24-29,36)$ and $\mathrm{CHL}$ \\
\hline \multirow{2}{*}{ Tumorigenic risk } & High & $5(3,5,14,18,20)$ and $\mathrm{CHL}$ \\
\cline { 2 - 3 } & Low & $8(6,21,22,24-28)$ \\
\hline \multirow{2}{*}{ Reproductive Effect } & High & $3(28,29,36)$ and $\mathrm{CHL}$ \\
\cline { 2 - 3 } & Low & $5(18,24-27)$ \\
\hline \multirow{2}{*}{ Irritant Effect } & Low & $/$ \\
\cline { 2 - 3 } & High & $\mathrm{CHL}$ \\
\hline
\end{tabular}

The majority of tested benzimidazole derivatives is considered non-toxic, and the irritating behaviour was not observed in any of the cases (Table 5). Compounds 14,18 and 20 are predicted to have high mutagenic and tumorigenic risks, whereas compounds 28, 29 and 36 are predicted to have a high mutagenic risk and a high reproductive effect. Compounds $6,19,21,22,24-27$ are predicted to have a high mutagenic risk, whereas compounds 3 and 5 are predicted to have a high tumorigenic risk. Chloram-phenicol is likely to exhibit all four toxic effects, where as ketoconazole and doxycycline are consider-ed safe to use.

Based on in silico evaluation of physicochemical properties, pharmacokinetic parameters and toxicity potential of benzimidazole derivatives, it was determined that the following nine compounds out of forty-two benzimidazole derivatives showed the best characteristics: 1, 2, 17, 32-35, 41, 42. The selected compounds, as well as all benzimidazole derivatives, met Lipinski's RO5 (Table 1); therefore, they express good oral availability. Their bioactivity score indicates high activity since they are predicted to react with more than four drug targets (Table 2). The absorption properties of compounds are satisfactory given the fact that all the mentioned components are expected to have good GIT absorption. The ability to pass through the hematoencephalic barrier is expected for all components except component 17, and none of the selected components is a substrate for P-gp (Table 3). Furthermore, metabolic properties are favourable since all the selected components are expected to inhibit not more than three CYP enzymes (Table 4), and to be non-toxic (Table 5). These are benzimidazoles that have high antifungal activity, proven by previous tests of antimicrobial activities $(6,14)$. Carboxy substituted (17) benzimidazole-hydrazone (Figure 1) exhibits two-fold better potency $(\mathrm{MIC}=25 \mu \mathrm{g} / \mathrm{mL}$ ) than the reference drug ketoconazole (MIC $=50 \mu \mathrm{g} / \mathrm{mL}$ ) against all analysed Candida fungal strains. On the other hand, their antibacterial activity is low (14). 1-Substituted-2methylbenzimidazoles $(32,33,34,35)$ and 1-substituted-2-aminobenzimidazoles $(41,42)$ show comparable antifungal activity to that of ketoconazole and amphotericin against $S$. cerevisiae (6). More- over, authors conclude that antifungal activity exhibited by the tested compounds is governed by the partition coefficient, log $P$.

Fundamental physiochemical properties of the central nervous system (CNS) drugs are evaluated on the basis of their ability to penetrate the bloodbrain barrier and to exhibit CNS activity. Lipophilicity and TPSA of drugs significantly influence their ability to penetrate the blood-brain barrier.

A drug targeting the CNS should ideally have a $\log P$ value around 2 . Benzimidazoles with $\log P$ values between 2 and 3 , i.e. molecules which are considered to be able to pass through the hematoencephalic barrier due to their optimal lipophilicity, are compounds 18-20, 37 and 40 (Table 1). Among these compounds, 1-benzylbenzimidazol-2-amine (37) and 2-amino-3H-benzimidazol-1-yl)-phenylmethano ne (40) (Figure 1) can be considered non-toxic (Table 5). Compounds 37 and 40 are expected to show high activity because they are predicted to react with more than four drug targets (Table 2). Also, both components are expected to have good GIT absorption and to be able to pass through the hematoencephalic barrier, whereas only compound 37 is predicted to be a prospective substrate for P-gp (Table 3 ). Compound 37 is expected to potentially inhibit four CYP enzymes, whereas compound 40 was expected to inhibit only CYP1A2 and CYP2C19 isoenzyme subfamilies. (Table 4). Those compounds were previously reported to express good antifungal activity against $\mathrm{S}$. cerevisiae (6).

The drugs can be targeted to the CNS with a PSA less than $60 \AA^{2}(24)$. Sixteen compounds, 1, 22, 24-26, 29-39, have slightly lower TPSA values below $60 \AA^{2}$, which indicates that they could pass through the hematoencephalic barrier (Table 1). Among benzimidazoles with lower TPSA values, ten compounds, $1,30-35$ and 37-39, can be considered non-toxic (Table 5). The properties of compounds 1 and 32-35 have already been discussed because they belong to the group of nine benzimidazoles with the best in silico analysis results. In addition to having high GIT, the rest of the selected compounds, 30, 31, 37-39, are predicted to pass through the $\mathrm{BBB}$, whereas the components 37-39 are P-gp substrates as well (Table 3). The selected CNS-permeable compounds 
are expected to inhibit four CYP isoenzymes, therefore, side effects are likely to appear (Table 4).

\section{Conclusion}

Based on the calculated physicochemical properties, we can conclude all of the benzimidazole derivatives have good oral bioavailability since they do not violate more than one RO5. Also, most of them (40 out of 42 ) have good intestinal absorption. Less than half of the compounds are expected to pass through the BBB, and a limited number of them is predicted to be P-gp substrates. The obtained results clearly reveal that the physiological actions of the analysed derivatives might involve multiple mechanisms, possibly the result of interactions with GPCR ligands, nuclear receptor ligands, inhibit protease, kinase and other enzymes. The most promising twenty-nine benzimidazoles are predicted to act by more than four mechanisms. Ketoconazole and chloramphenicol could influence on all tested drug targets, while doxycycline is a little less active due to the lack of kinase and enzyme inhibitors' activity. Seven compounds are predicted to inhibit all the listed CYP isoenzymes. The majority of tested benzimidazole derivatives is considered safe to use, and the irritating behaviour was not observed in any of the cases. Chloramphenicol is likely to exhibit all four toxic effects, whereas ketoconazole and doxycycline are considered non-toxic. Methods of a computer based (in silico) analysis could be very useful in the discovery of new drug candidates.

\section{Acknowledgments}

The financial support to this work by the Ministry of Education, Science and Technological Development of the Republic of Serbia (Project OI 172044) is gratefully acknowledged. 


\section{References}

1. Bayrak H, Demirbas A, Karaoglu SA, Demirbas $N$. Synthesis of some new 1, 2, 4-triazoles, their Mannich and Schiff bases and evaluation of their antimicrobial activities. Eur J Med Chem 2009; 44(3):1057-66. [CrossRef] [PubMed]

2. Bansal $Y$, Silakari $O$. The therapeutic journey of benzimidazoles: A review. Bioorg Med Chem 2012; 20 (21):6208-36. [CrossRef] [PubMed]

3. Yadav G, Ganguly S. Structure activity relationship (SAR) study of benzimidazole scaffold for different biological activities: A mini-review. Eur J Med Chem 2015; 97:419-43. [CrossRef] [PubMed]

4. Arjmand F, Parveen S, Afzal M, Shahid M. Synthesis, characterization, biological studies (DNA binding, cleavage, antibacterial and topoisomerase I) and molecular docking of copper(II) benzimidazole complexes. J Photochem Photobiol B 2012; 114:15-26. [CrossRef] [PubMed]

5. Bandyopadhyay P, Sathe M, Ponmariappan S, Sharma A, Sharma P, Srivastava AK, et al. Exploration of in vitro time point quantitative evaluation of newly synthesized benzimidazole and benzothiazole derivatives as potential antibacterial agents. Bioorg Med Chem Lett 2011; 21(24):7306-09. [CrossRef] [PubMed]

6. Podunavac-Kuzmanovic SO, Barna DJ, Cvetkovic, DD. Quantitative structure-activity relationships to predict antibacterial effect of some benzimidazole derivatives. Acta Period Technol 2008; 39:181-91. [CrossRef]

7. Kilcig GA, Altanlar N. Synthesis and antifungal activity of some benzimidazole derivatives. Turk J Chem 2006; 30(2):223-8.

8. Kubo K, Kohara $Y$, Yoshimura $Y$, Inada $Y$, Shibouta $Y$, Furukawa $Y$, et al. Nonpeptide angiotensin II receptor antagonists. Synthesis and biological activity of potential prodrugs of benzimidazole-7-carboxylic acids. J Med Chem 1993; 36(16):2343-9.

[CrossRef] [PubMed]

9. Sabat M, VanRens JC, Laufersweiler MJ, Brugel TA, Maier J, Golebiowski A, et al. The development of 2benzimidazole substituted pyrimidine based inhibitors of lymphocyte specific kinase (Lck). Bioorg Med Chem Lett 2006; 16(23):5973-7. [CrossRef] [PubMed]

10. Fonseca T, Gigante B, Marques MM, Gilchrist TL, De Clercq E. Synthesis and antiviral evaluation of benzimidazoles, quinoxalines and indoles from dehydroabietic acid. Bioorg Med Chem 2004; 12(1):103-12. [CrossRef] [PubMed]

11. Gurer-Orhan H, Orhan H, Suzen S, Püsküllü MO. Buyukbingol E. Synthesis and evaluation of in vitro antioxidant capacities of some benzimidazole derivatives. J Enzyme Inhib Med Chem 2006; 21(2):241-7. [CrossRef] [PubMed]
12. Refaat HM. Synthesis and anticancer activity of some novel 2-substituted benzimidazole derivatives. Eur J Med Chem 2010; 45(7):2949-56.

[CrossRef] [PubMed]

13. Zhao Z, Arnaiz DO, Griedel B, Sakata S, Dallas JL, Whitlow $M$, et al. Design, synthesis, and in vitro biological activity of benzimidazole based factor Xa inhibitors. Bioorg Med Chem Lett 2000; 10(9):963-6. [CrossRef] [PubMed]

14. Özkay $Y$, Tunalı $Y$, Karaca H, Işıkdağ I. Antimicrobial activity of a new series of benzimidazole derivatives. Arch Pharm Res 2011; 34(9):1427-35.

[CrossRef] [PubMed]

15. Mavrova A, Yancheva D, Anastassova N, Anichina $K$, Zvezdanovic J, Djordjevic A, et al. Synthesis, electronic properties, antioxidant and antibacterial activity of some new benzimidazoles. Bioorg Med Chem 2015; 23(19):6317-26. [CrossRef] [PubMed]

16. ChemDraw.

http://www.cambridgesoft.com/software/overview.as px

17. Molinspiration Cheminformatics, 2016. Molinspiration property engine v2016.09. http://www.molinspiration.com/cgi-bin/properties

18. SwissADME. http://www.swissadme.ch/

19. OSIRIS Data Warrior v.4.7.2 http://www.openmolecules.org/datawarrior/

20. Lipinski CA, Lombardo F, Dominy BW, Feeney PJ. Experimental and computational approaches to estimate solubility and permeability in drug discovery and development settings. Adv Drug Deliv Rev 2001; 46 (1-3):3-26. [CrossRef] [PubMed]

21. Veber DF, Johnson SR, Cheng HY, Smith BR, Ward $\mathrm{KW}$, Kopple KD. Molecular properties that influence the oral bioavailability of drug candidates. J Med Chem 2002; 45(12):2615-23. [CrossRef] [PubMed]

22. Keller TH, Pichota A, Yin Z. A practical view of "druggability". Curr Opin Chem Biol 2006; 10(4):357-61. [CrossRef] [PubMed]

23. Cortes C, Vapnik V. Support vector machine. Mach Learn 1995; 20(3):273-297. [CrossRef

24. Prasanna $S$, Doerksen RJ. Topological polar surface area: a useful descriptor in 2D-QSAR. Curr Med Chem 2009; 16(1):21-41. [CrossRef] [PubMed]

25. Montanari F, Ecker GF. Prediction of drug-ABC-transporter interaction-Recent advances and future challenges. Adv Drug Deliv Rev 2015; 86:17-26. [CrossRef] [PubMed]

26. Daina A, Michielin O, Zoete V. SwissADME: a free web tool to evaluate pharmacokinetics, drug-likeness and medicinal chemistry friendliness of small molecules. Sci Rep 2017; 7:42717. [CrossRef] [PubMed] 


\title{
IN SILICO ISPITIVANJE ODABRANIH DERIVATA BENZIMIDAZOLA U POTRAZI ZA NOVIM POTENTNIM ANTIMIKROBNIM AGENSIMA
}

\author{
Jelena V. Živković, Sandra G. Kalauzović, Maja R. Milosavljević, Kristina G. Kalauzović
}

Univerzitet u Nišu, Medicinski fakultet, Katedra za farmaciju, Niš, Srbija

Kontakt: Jelena V. Živković

Bul. dr Zorana Đinđića 81, 18000, Niš, Srbija

E-mail: jelena.zivkovic.hemija@medfak.ni.ac.rs

Benzimidazoli su heterociklična jedinjenja koja predstavljaju farmakofore mnogih lekova. Pored antimikrobne (antibakterijske i antifungalne) aktivnosti, derivati benzimidazola su izuzetno efikasna jedinjenja koja pokazuju širok spektar bioloških aktivnosti. Korišćenjem kompjuterskih programa Molinspiration, SwissADME i OSIRIS Data Warrior, ispitivane su farmakokinetičke i toksikološke osobine četrdeset dva derivata benzimidazola. Jedinjenja su ispunila sve kriterijume za zadovoljavajuću oralnu bioraspoloživost. Za većinu je predviđeno da su netoksična, a potencijalno iritantno delovanje nije utvrđeno ni u jednom slučaju. $\mathrm{Na}$ kraju, na osnovu povoljnih farmakokinetičkih parametara i toksikoloških karakteristika selektovano je devet najobećavajućih derivata. Sposobnost prolaska kroz hematoencefalnu barijeru se očekuje za sve komponente osim jedne, a nijedna od odabranih nije supstrat za Pglikoprotein. Metaboličke karakteristike selektovanih jedinjenja su takođe povoljne, jer se predviđa inhibicija ne više od tri citohrom P450 izoenzima i odsustvo toksičnosti.

Acta Medica Medianae 2019;58(1):106-115.

Ključne reči: antimikrobni agensi, benzimidazoli, bioraspoloživost, in silico ispitivanje, toksikološke osobine 